\title{
Wolfenzon, C. (2016). Muerte de Utopía. Historia, antihistoria e insularidad en la novela latinoamericana. Lima: Instituto de Estudios Peruanos.
}

Desde el clásico estudio La novela histórica (1937), de Georg Lukács, hasta Latin America's New Historical Novel (1993), de Seymour Menton, por mencionar dos libros centrales en la hermenéutica de un género narrativo específico, la mayoría de los estudios sobre la novela histórica han abordado análisis independientes de estas obras como subgénero narrativo. Por ese motivo, Carolyn Wolfenzon, en Muerte de Utopía. Historia, antihistoria e insularidad en la novela latinoamericana, propone una sistematización integradora mayor de un conjunto de novelas históricas latinoamericanas; así, en su investigación no se examina esta narrativa de manera autónoma y segregada, sino que pretende conectarlas y unificarlas a través de sus características, con la finalidad de sumar nuevas lecturas de corte teórico.

En su estudio introductorio, la autora traza tres conceptos centrales para sus análisis: la insularidad, la historia y la antihistoria. Tales criterios le sirven para explicar el discurso histórico que presenta el corpus narrativo elegido e identificado por tener como eje común una "[r]eacción ante un poder ajeno" (p. 31). El concepto de insularidad en la literatura se explica como aquel espacio apartado que invita a la reflexión de la historia. Por otro lado, la categoría de antihistoria permite suprimir la historia y replantearla desde otras perspectivas. En tal sentido, a través de un marco teórico de análisis excepcionales que abordan la cuestión de la novela histórica latinoamericana, Wolfenzon plantea cómo estas categorías se desarrollan en sus objetos de estudio, puesto que, como espacios literarios reflexivos e insulares, no mantienen una linealidad temporal e histórica, sino que se enfrentan a este concepto mediante la antihistoria.

El primer capítulo se centra en Zama (1956) de Antonio Di Benedetto. El género literario de esta novela ha sido discutido por la crítica, sin embargo, Wolfenzon la reconoce como una novela histórica por dos razones. La primera es la recreación temporal de la región del $\mathrm{Pa}$ raguay colonial (cuando era parte del virreinato del Río de la Plata), como lugar marginal, donde esta condición insular simboliza el "distanciamiento del orden, el poder y el sentido" (p. 35) y se enfatiza por la retórica utilizada por Di Benedetto. El segundo, es porque narra la biografía de Miguel Gregorio de Zamalloa, personaje y período en el que pudo inspirarse el autor de la novela. Luego, Wolfenzon formula el concepto de la "doble historicidad", para aludir a la Argentina peronista de la década del 50. Asimismo, el reconocimiento de Paraguay no solo debe reflexionarse de modo geográfico, sino por su "posición insular y periférica del lugar y del personaje; y, por extensión, la señal de marginalidad e insularidad de la condición latinoamericana" (p. 55), pues predomina la situación de dependencia hacia la metrópoli. Sin embargo, el personaje don Diego de Zama, como receptor de la historia, no puede transformar la historia y esa tensión, entre la realidad y la ley, lo conduce a la locura.
Luego, el segundo capítulo se enfoca en El mundo alucinante (1965) de Reinaldo Arenas. Se establece una comparación con la anterior novela, puesto que este protagonista, fray Servando, condena al sistema y se esfuerza por transformarlo. Este personaje marginal, comparado a un pícaro, lucha contra la ideología dominante, contradice la tradición hispánica y permite revalorar la cultura autóctona. En esta novela, Wolfenzon señala que el palacio es una isla donde el protagonista se encuentra recluido, un lugar insular que "produce la sensación de libertad aparente cuando en realidad es una cárcel" (p. 110), pues este espacio funciona como enlace entre la ideología religiosa y política. No obstante, si bien se respetan los acontecimientos, el tiempo plantea una circularidad que sirve para negar el progreso de la historia y criticar la modernidad, a estos se le añade la parodia, que funciona para enfatizar la estructura narrativa.

En el tercer capítulo se estudian dos novelas de Carmen Boullosa: Cielos de la Tierra (1997) y Duerme (1994). Ambas novelas resaltan a la mujer, quien es visualizada como la promesa para una rebelión futura que integre a la nación de México, bajo un rol de traducción y mediación. Sin embargo, ella no forma parte de lo nacional, sino que se encuentra apartada en un espacio insular y marginal, pues su identidad ha sido construida y asociada con la Malinche, sinónimo de traición por el discurso predominante. Wolfenzon señala que quienes narran estas historias marginales son el indio y la mujer, personajes que fueron relegados y que ahora son escuchados en las novelas de Boullosa, por su característica antihistórica, donde la mujer lucha en contra de la injusticia social.

En el correspondiente cuarto capítulo se aborda dos novelas de Enrique Rosas Paravicino: El gran señor (1994) y Muchas lunas en Machu Picchu (2006). En ambos textos se resalta el sincretismo de los Andes, que forma parte del mestizaje social, cultural y mental, el cual es una suma heterogénea de elementos españoles con autóctonos. Estas historias andinas son la representación de una "tragedia cíclica", el tiempo antihistórico, la circularidad que repite la historia: primero con Túpac Amaru I y, luego, con Túpac Amaru II. En tal sentido, Wolfenzon propone como espacios insulares, y exóticos a la vista occidental, a la puna y al Ausangate, el cual es "un espacio aislado e incomprensible para la cultura occidental" (p. 207) que, pese a los elementos modernizadores, no es capaz de integrar a los peruanos y causa enfrentamientos continuos. Por ello, Sendero Luminoso concibe la historia con un carácter antihistórico, sin comprender el significado de sincretismo y de la resignificación que la cultura andina ha logrado frente a la cultura occidental.

El quinto capítulo está dedicado a dos novelas de Abel Posse: Daimón (1978) y El largo atardecer del caminante (1992). El novelista argentino se centra en el período del "descubrimiento" de América y construye su 
historia a partir de las versiones de los vencidos, pues la escritura unilateral descalificaba a América frente a la superioridad española. En ambas novelas, Posse tergiversa y manipula la historia, e imposibilita el entendimiento pacífico entre ambas culturas. La primera novela tiene como personaje atípico a Lope de Aguirre, quien deja su mentalidad occidental por la cosmovisión indígena; mientras que la segunda, a Cabeza de Vaca, quien intenta imponer su cultura a través de la monogamia y la religión católica. A través de estas luchas entre los personajes españoles y los indios, Wolfenzon afirma que: "Existe una lucha entre opresores y oprimidos, donde estos últimos se vuelven los nuevos opresores" (p. 258), por lo tanto, se niega el entendimiento intercultural me- diante una postura posmoderna que cambia y omite la historia dentro de la ficción.

Finalmente, la sexta parte es un apartado donde Carolyn Wolfenzon asevera que "la novela histórica en Latinoamérica se caracteriza por revertir y cuestionar la historia oficial" (p. 263) y, por consiguiente, se identifica por su antihistoricidad, así como con las distintas formas de representación. Frente a ello, la sistematización en Muerte de Utopía. Historia, antihistoria e insularidad en la novela latinoamericana logra analizar y, sobre todo, articular este corpus novelístico bajo una nueva propuesta que permitirá estudios posteriores sobre la novela histórica latinoamericana.

\section{Susan Llontop Gutiérrez}

Universidad Nacional Mayor de San Marcos, Lima, Perú

Contacto: susan.Ilontop@unmsm.edu.pe

https://orcid.org/0000-0002-0848-3444 